\title{
Polyphenols in Fruits and Vegetables and Its Effect on Human Health
}

\author{
Giuseppina Pace Pereira Lima ${ }^{1}$, Fabio Vianello², Camila Renata Corrêa ${ }^{3}$, \\ Renê Arnoux da Silva Campos ${ }^{1}$, Milena Galhardo Borguini' ${ }^{1}$ \\ ${ }^{1}$ Department of Chemistry and Biochemistry, São Paulo State University, UNESP, Botucatu, São Paulo, Brazil \\ ${ }^{2}$ Department of Comparative Biomedicine and Food Science, University of Padova, Padova, Italia \\ ${ }^{3}$ Department of Internal Medicine, Botucatu Medical School, São Paulo State University, UNESP, Botucatu, São \\ Paulo, Brazil \\ Email: ${ }^{*}$ gpplima@ibb.unesp.br
}

Received 20 December 2013; revised 22 April 2014; accepted 30 April 2014

Copyright (C) 2014 by authors and Scientific Research Publishing Inc.

This work is licensed under the Creative Commons Attribution International License (CC BY). http://creativecommons.org/licenses/by/4.0/

(c) (i) Open Access

\section{Abstract}

Polyphenols represent a group of chemical substances common in plants, structurally characterized by the presence of one or more phenol units. Polyphenols are the most abundant antioxidants in human diets and the largest and best studied class of polyphenols is flavonoids, which include several thousand compounds. Numerous studies confirm that they exert a protective action on human health and are key components of a healthy and balanced diet. Epidemiological studies correlate flavonoid intake with a reduced incidence of chronic diseases, such as cardiovascular disease, diabetes and cancer. The involvement of reactive oxygen species (ROS) in the etiology of these degenerative conditions has suggested that phytochemicals showing antioxidant activity may contribute to the prevention of these pathologies. The present review deals with phenolic compounds in plants and reports on recent studies. Moreover, the present work includes information on the relationships between the consumption of these compounds, via feeding, and risk of disease occurrence, i.e. the effect on human health. Results obtained on herbs, essential oils, from plants grown in tropical, subtropical and temperate regions, were also reported.

\section{Keywords}

Fruits, Vegetables, Consume, Effect on Human, Phenolic Content, Thermal Processing, Absorption

\section{Introduction}

Phenolic compounds, or polyphenols, constitute one of the most numerous and widely distributed group of sub-

\footnotetext{
${ }^{*}$ Corresponding author.
}

How to cite this paper: Lima, G.P.P., Vianello, F., Corrêa, C.R., da Silva Campos, R.A. and Borguini, M.G. (2014) Polyphenols in Fruits and Vegetables and Its Effect on Human Health. Food and Nutrition Sciences, 5, 1065-1082. 
stances in the plant kingdom, with more than 8000 phenolic structures currently known [1]. Phenolic compounds structurally differ from simple molecules, such as phenolic acids, and from highly polymerized compounds, such as proanthocyanidins (tannins), which occur in plants and are common in many foods (fruits, vegetables, cereal grains) and beverages (wine, beer, teas) [2]. The most common phenolics in human diet are phenolic acids, flavonoids and tannins [3]. Phenolic compounds have at least one aromatic ring with one or more hydroxyl groups, and may be classified as flavonoids and non-flavonoids [4].

The polyphenols can be divided, depending on their basic chemical structure into at least 10 different classes. The flavonoids constitute one of the most important group, and they can be further subdivided into 13 different classes, with more than 5000 compounds described. During last years, the interest on polyphenols and other molecules with antioxidant activity has increased among agricultural and food scientists, nutritionists, food industry professionals and consumers [1].

Polyphenols provide health benefits by several mechanisms, including the elimination of free radicals, the protection and regeneration of other dietary antioxidants (e.g. vitamin E) and the chelation of pro-oxidant metals. The nature and content of phenolics varies dramatically among plants, which are mainly esterified or glycosylated [5]. They possess beneficial properties, such as antioxidant, immune modulatory actions and anti-cancer and antibacterial activity. Some studies evidenced an improvement of wound healing by these phyto-chemicals [6].

Several studies have demonstrated the antioxidant activity exerted by polyphenols, as flavonoids, especially regarding the scavenging of various oxidizing species, superoxide anion, hydroxyl radical and peroxyl radicals [1]. Flavonoids are structurally characterized by a di-phenyl-propane moiety (C6-C3-C6), naturally occurring in plants [7], and can be divided into six different classes: flavones, flavonols, anthocyanidins, flavanones, isoflavones and flavan-3-ols. Besides their antioxidant potential, flavonoids possess other properties, such as an antimutagenic activity, reducing the risk of cardiovascular diseases, anti-proliferative action on tumor cells, atherosclerosis protection, radio-protective action, hair tonic, hormonal repository in natural menopause women and antimicrobial properties [8]. Obviously all these pathologies and proliferative diseases are multifactorial and multivariate, and are intrinsically related to individual's genetics. The adsorption of these substances occurs preferentially in the intestine, particularly glycosylated forms [9] [10].

Various specific biochemical properties of polyphenols are known. For example, an interesting functional property of flavonoids (quercetin and genistein) is the competitive inhibition of tyrosine kinase on its ATP binding site. This enzyme is a membrane receptor characterized by a remarkable enzymatic activity, and an increase in its expression level may trigger various proliferative diseases, such as cancer and psoriasis [11].

Polyphenol content in foods and beverages can be determined by several methods, each one presenting its own advantages and disadvantages. Generally, the method of choice is represented by high-performance liquid chromatography (HPLC), equipped with mass spectrometry detection and appropriate isotopically labeled standards, but these are rarely available and mass spectrometers are expensive. Some easy-to-use and cheap methods have been developed to measure the total polyphenol content, such as Folin Ciocalteu reagents [12]. These determination methods, generally colorimetric, are based on the chemical properties of phenolic substances.

In this review, we present the benefits of the intake of polyphenols, as well as the mode of cultivation to improve the content of these bioactives in foods, types of foods richest and absorption. Moreover, we mention some studies that confront the excessive consumption of polyphenols and possible damage to health.

\section{Polyphenol as Natural Antioxidant}

Most of these substances are classified as natural antioxidants, which reveal their importance under oxidative stress. Some synthetic phenolic antioxidants are currently used in food industry, such as butylated hydroxyanisol (BHA), butylated hydroxytoluene (BHT), tert-butylhydroquinone (TBHQ), 2-tert-butyl-4-methylphenol (TBMP), and gallic acid esters, e.g. propyl gallate (PG). These synthetic antioxidants are considered harmful to human health. High doses of TBHQ exert negative health effects on laboratory animals, such as DNA damage, which may lead to stomach tumors [13]. BHA has been reported to act as a tumor initiator and tumor promoter in some animal tissues [14].

The current preoccupation about adverse effects of synthetic antioxidants should be considered and some foods, drinks and medicinal plant extracts may represent an alternative source of natural antioxidants. Plant extracts and essential oils can be used as an accessible source of natural antioxidants and a possible food supplement, or exploited for pharmaceutical applications. Furthermore, plant phenolics can be used as additives against 
oxidative deterioration in processed food industry [15].

Phenolic compounds (Figure 1), as other antioxidants, are generally used to decrease the deleterious effects of substances with high oxidative potential. The antioxidant properties of polyphenols are mainly due to their redox properties, which allow them to act as reducing agents, hydrogen donors and singlet oxygen quenchers [16]. Among compounds characterized by oxidant activity, i.e., reactive oxygen species, superoxide radical $\left(\mathrm{O}_{2}^{*}\right)$, hydrogen peroxide $\left(\mathrm{H}_{2} \mathrm{O}_{2}\right)$, hydroxyl radical $\left(\mathrm{OH}^{*}\right)$ and singlet oxygen $\left({ }^{1} \mathrm{O}_{2}\right)$, can be found [17].

\section{Phenolic Compounds and Free Radicals}

The elimination of free radicals is not favored under normal physiological conditions, owing to their low concentrations. Therefore, the primary defense against these species, and therefore for the interruption of radical chain reactions, depends on the actions of substances known as antioxidants. These compounds act by reducing free radicals and reactive species, thus preventing injuries and oxidative deterioration of cell structures. Under constant exposure to high concentrations of these harmful agents, repairing system (antioxidants) cannot overcome the demand, leading to the occurrence of an accumulation of reactive species, giving rise to the so-called oxidative stress. Oxidative stress is therefore an imbalance between the production of oxidative species and the protection system by antioxidants, leading cell damage, directly related to chronic degenerative pathology, as reported by several reports [18]-[21].

Free radicals may readily react with various compounds, capturing electrons necessary to improve their stability. Generally, these reactions are very fast, and the kinetics is controlled by the diffusion rate of reactants. Thus, free radicals in solution react with the nearest molecules, capturing one of their electrons. When this target molecule loses one electron, it becomes a free radical itself, with the possibility to initiate a radical chain reaction, such as the well known lipid peroxidation, resulting in the damage and even disruption of cell membranes. The same oxidation phenomenon may also occur on proteins and DNA, resulting in cellular degradation [22].

Free radicals are naturally produced in the body by several metabolic reactions, such as mitochondrial respiration and enzymatic oxidations catalyzed by oxidases. Thus, to minimize harmful effects resulting from the action of free radical compounds, enzymatic antioxidant defense systems are active, involving oxydo-reductases, such as superoxide dismutases (SOD), peroxidases (POD), catalase (CAT) and glutathione peroxidase (GPx) [23]. Furthermore, non-enzymatic antioxidant systems, such as reduced glutathione (GSH), ascorbic acid, $\alpha$-tocopherol, $\beta$-carotene and polyphenols [23], are available inside organisms. Thus, an increasing demand for foods characterized by a high antioxidant content and high nutritional quality, may lead to a desired increase in the consumption of specific fruits and vegetables. Accordingly, "functional foods" were introduced with the aim to increase the intake of bioactive compounds with potential beneficial actions, including polyphenol rich foods, to

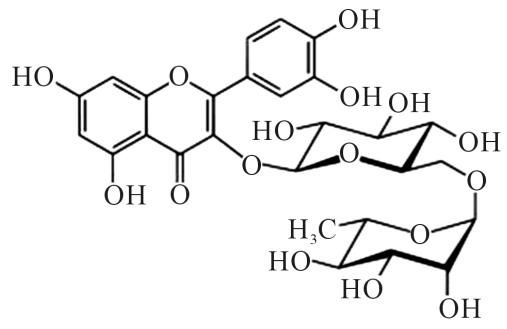

Rutin<smiles>O=c1cc(-c2ccccc2)oc2cc(O)cc(O)c12</smiles>

Chrysin<smiles>Oc1ccc(/C=C/c2cc(O)cc(O)c2)cc1</smiles>

Resveratrol<smiles>COc1cc(/C=C/C(=O)CC(=O)/C=C/c2ccc(O)c(OC)c2)ccc1O</smiles>

Curcumin

Figure 1. Structure of some polyphenols [1]. 
avoid or reduce the action of free radicals in vivo. Even the consumption of red wine, characterized by high levels of polyphenols and bioactive substances, such as resveratrol, was epidemiologically related to the low incidence of coronary heart disease (CHD), as stated by the French paradox. According to this assumption, a population (in France) consuming a diet rich unsaturated fatty acids, presents a lower incidence of cardiovascular diseases, compared with populations with similar diet, due to the habit to consume red wine, containing polyphenols with the ability to inhibit platelet aggregation and to protect low density lipoproteins (LDL) from oxidation [24] (Figure 2). It should be remembered that French people uses to feed according to the Mediterranean diet, rich in fruits and red wine, which has been shown to protect against the occurrence of coronary events [25].

Oxidative stress is classically defined as a series of events resulting in an imbalance between oxidant and antioxidant reactions [26] [27]. Both classes of substances (oxidants and antioxidants) are generated in an oxidation-reduction scenario, where oxidations involve electron loss and reduction, electron gain. Thus, many authors use the term "redox imbalance" referring to oxidative stress [28]-[30].

\section{Oxidative Stress and Phenolic Compounds in Foods}

Popularly known as free radicals, oxidant substances include reactive oxygen (ROS) and nitrogen species (RNS). Reactive species are commonly identified as substances leading to the oxidation of lipids (lipoxidation), glucose (glycation) and proteins (carbonylation). The reaction products generated in lipoxidation are represented by malondialdehyde, glyoxal, acrolein, 4-hydroxy-nonenal (HNE). Those generated by glycation are methylglyoxal and glyoxal. These compounds react with proteins and aminoacids resulting in amino-glycated end products (AGEs) [31]. AGEs are involved in common events, which may trigger obesity and insulin resistance, diabetes mellitus II and inflammation [32]-[34], and could correspond to important activators of inflammation in various tissues. The action of these products occurs as they bind to the RAGE receptor (receptor of glycation end products), initiating the cascade of events involving the action of kinases, that culminate in the activation of Ikk $\beta$ / NFkB, a nuclear transcription factor related to inflammation [35]. The polyphenols can block this inflammatory cascade [35], see Figure 3. In the presence of increasing food intake, oxidations occur. For example, glucose

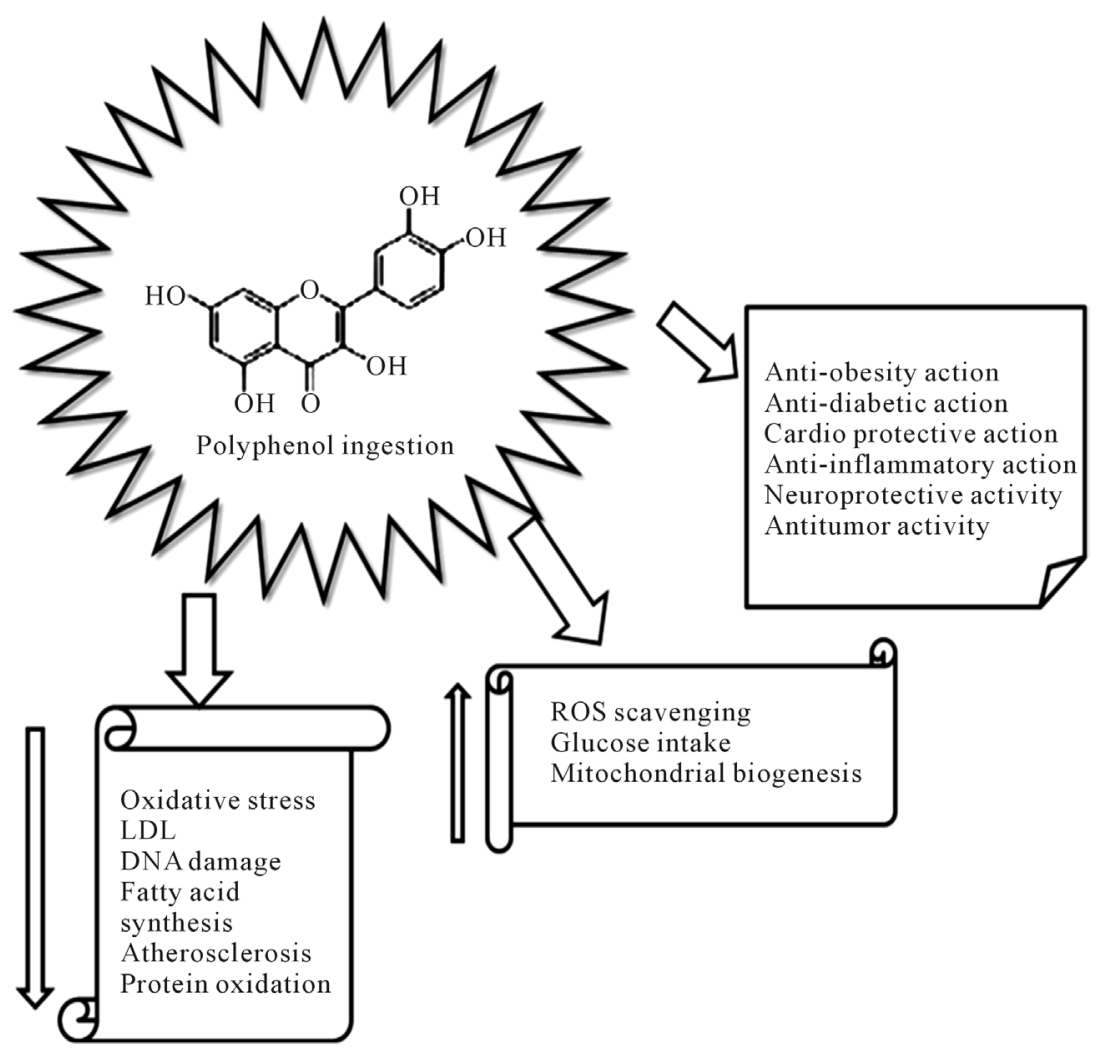

Figure 2. Suggested protection of polyphenol ingestion. 


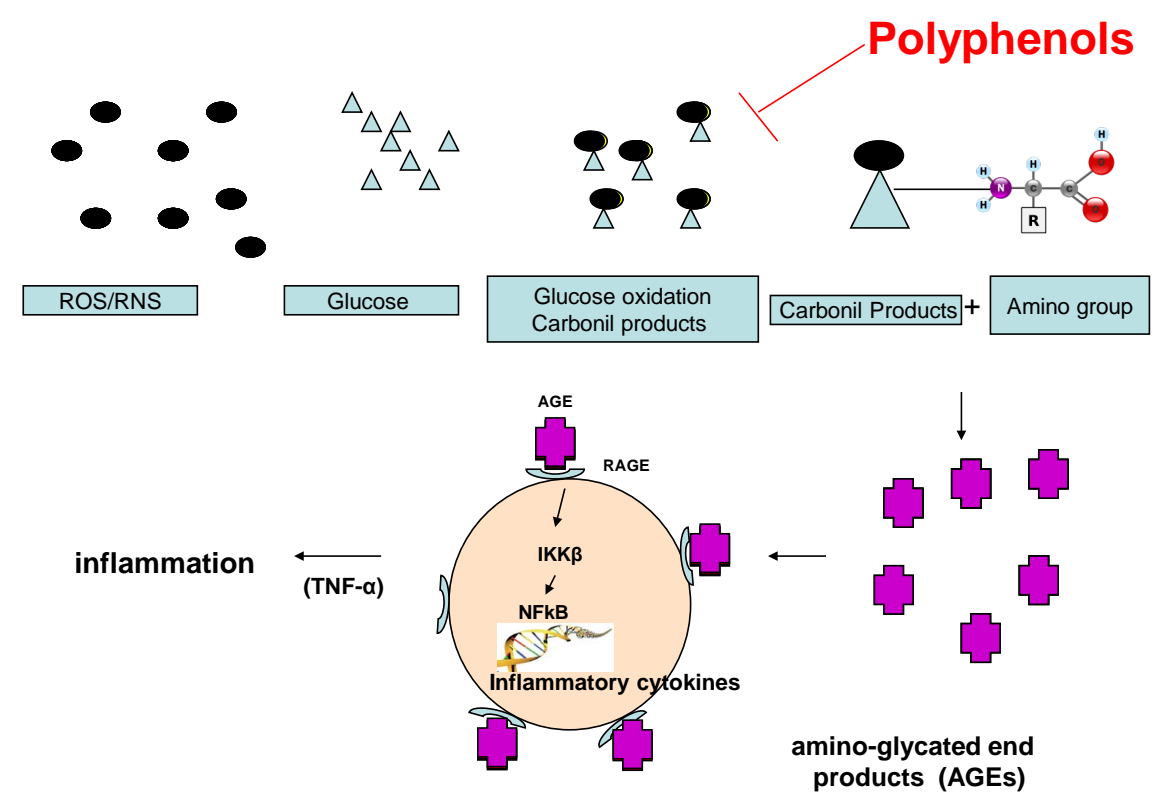

Figure 3. Inhibition inflammatory process by polyphenols.

may be oxidized by reactive species, becoming a carbonyl toxic product. This, in turn, may attack the amino group of the amino acids, forming glycation end products (AGEs), which are very reactive and may trigger the release of cytokines, resulting in inflammation in tissues exposing RAGE receptors, such as in kidney, heart and blood vessels. Polyphenols may block the formation of reactive products, thereby decreasing the inflammatory process.

Some studies showed that RAGE receptor is expressed in some organs, such as kidneys [36], blood vessels [37] and adipose tissue [38]. The formation of the AGEs/RAGE complex could trigger inflammatory processes affecting these tissues. Thus, AGEs/RAGE complex represents the interface between oxidative stress and inflammatory system.

It is important that antioxidants are constantly present in the body, controlling the effects of oxidants. Therapies using antioxidants have been studied in order to mitigate the overproduction of reactive oxygen (ROS) and nitrogen (RNS) species. Several epidemiological studies have shown that diets rich in fruits and vegetables, which are sources of carotenoids and polyphenols, are correlates with a reduced risk of chronic diseases onset [39]-[41]. Thus, it is likely that antioxidant nutrients in foods can prevent damages caused by ROS/RNS (see Figure 2). As above mentioned, the redox status depends on the balance between the production of reactive oxygen/nitrogen species (ROS/RNS) by oxidative stress, and their removal by the antioxidant defense system. Oxidants and antioxidants have been found at tissue, cellular, and molecular levels and are subdivided according to their water/lipid solubility, and endogenous/exogenous (dietary) sources [42].

Phenols from numerous plant species have been actively studied as potential treatments for various metabolic and cardiovascular diseases. For example, resveratrol from red wine [43] [44], epigallocathechin-3-gallate from green tea [45]-[47], curcumin from turmeric [48], and quercetin [49] [50] (Figure 1) from different sources have all been studied as potential therapeutic agents. Furthermore, a dose dependent scavenging activity of antioxidants on free radicals was observed, leading to an increase of cell lifespan [51]. Thus, the antioxidant potential of polyphenols is mainly related to the ability of these compounds to scavenge free radicals produced by oxidative stress [52]. Several studies focused on food polyphenol content, carried out on humans, have shown the beneficial effects of grape seeds, chokeberries, coffee, carob, and cocoa [53]. Studies involving supplementation of antioxidants to prevent oxidative and inflammatory actions in obese patients have also been performed. Hogan et al. [54] examined the effect of grape skins, which represent a rich source of polyphenols, on blood parameters related to oxidative stress and inflammation in obese mice. Results showed that grape skins improved the physiological indicators related to oxidative stress and inflammation in obese animals, compared to controls.

Other antioxidants may also interfere with the inflammatory state of obesity. A recent review [55] highlighted the improvement of the physiogical status in obesity, regarding inflammation and oxidative stress, due to the use 
of curcumin, a polyphenolic spice used in Oriental cuisine. Its concentration can vary from $1.5 \%$ to $7.1 \%$ in turmeric rhizomes (Curcuma longa) [56]. Curcumin has attracted considerable interest in recent years due to its high medicinal potential: it is a potent immune modulatory agent, presenting antioxidant, anti-fibrotic, anti-viral and anti-infective effects [57] [58]. This anti-inflammatory compound is able to inhibit the transcriptional factor $\mathrm{kB}(\mathrm{NFkB})$, which belongs to a group of transcriptional factors inducing cytokine production, which is activated in the response to stress [59].

The risk to develop osteoporosis is four times higher in postmenopausal women than in men due to the decreased estrogen levels after menopause and represents the highest osteoporosis risk in the whole population [60]. Etiological risk factors associated with osteoporosis include poor nutrition, imbalanced cytokines and hormones, and aging process [61]. It has been noticed that reactive oxygen species (ROS) play a key role in the aging process, and greatly contribute to osteoporosis [62]. The role of ROS in the pathology of osteoporosis has been reviewed in detail by Manolagas [63], including the influences on the generation and survival of osteoclasts, osteoblasts, and osteocytes. It was found that excess ROS can lead to DNA damage, with the formation of 8-hydroxy-2-deoxyguanosine (8-OHdG), an oxidative biomarker that has been widely used in humans to indicate the oxidative stress status [64] [65].

Green tea polyphenols, extracted from green tea, have shown their osteo-protective effects by decreasing oxidative stress, increasing the activity of antioxidant enzymes, and decreasing the expression of pro-inflammatory mediators in rodent models [66]. The beneficial effects of green tea polyphenols on bone health has been reviewed [67]. Biomarkers of green tea consumption using green tea components have been validated in human studies, and diet supplementation with green tea polyphenols has demonstrated to be protective against cancer [68], cardiovascular diseases [69], and neurodegenerative diseases [70], and also can effectively reduce oxidative stress biomarkers in post-menopausal women with osteopenia [71].

Cancer is widely perceived as a heterogeneous group of disorders, which is caused by a series of clonally selected "genetic" changes in key tumor suppressor genes and oncogenes. However, accumulating evidences in recent years indicate that tumor cell heterogeneity is, at least in part, due to the significant contribution of 'epigenetic' alterations in cancer cells [72]. Among the risk factors related to the development of some cancers, such as esophagus, are represented by habits, such as alcohol consumption and smoking. Some studies showed that consumption of green vegetables and fruits exert a protective effect regarding this pathology [73]. Neves et al. [74] cited several studies showing as the usual diet is an important factor involved in the onset of colon and rectum cancer. Among the risk factors, a diet rich in animal fats and low fruit, vegetable and cereal intake stands out. These foods, especially fruits and vegetables, have been suggested to have a protective effect against prostate cancer [75] because they contain antioxidant substances, such as polyphenols.

Green tea may be associated with a decreased risk of advanced prostate cancer. A study carried out on 49,920 men, aged 40 - 69, who completed a questionnaire that included their green tea consumption showed that the green tea consumption was not associated with localized prostate cancer. However, it was associated, in a dosedependent manner, to the decreasing risk of advanced prostate cancer. The multivariate relative risk was 0.52 (95\% confidence interval) for men drinking 5 or more tea cups/day, compared with patients consuming less than 1 cup/day. Thus, green tea consumption may be associated with a decreased risk of advanced prostate cancer [76]. Polyphenols found in green tea, such as quercetin, rutin, myricetin, chrysin, epigallocatechin-3-gallate, epicatechin, catechin, resveratrol, and xanthohumol, were also tested on colorectal cancer cells. The work was performed in cell culture models and concluded that these compounds inhibit cell growth, by inducing cell cycle arrest and/or apoptosis, inhibiting, as well, cell proliferation, angiogenesis, and metastasis, and exhibiting antiinflammatory and/or antioxidant effects [77].

\section{Factors Influencing Food Phenolic Content}

Non-nutritive, health-promoting, bioactive components present in foods have the potential to exert beneficial effects against many chronic diseases [78]. Besides their nutraceutical properties, polyphenols are indicative of the quality of fruits and vegetables. The effectiveness of the antioxidant action of these bioactive compounds depends on their chemical structure and concentration in foods [79] and many factors can influence the polyphenol content in plants. One of these is the type of cultivation, such as organic or conventional.

Several studies have demonstrated that organic cultivation increases polyphenolic compound content in vegetables. It was found significant differences in the level of flavonoids in strawberries (Fragaria $\times$ ananassa), 
blackberries (Rubus sp) and in maize (Zea mays) grown under organic cultivation. Moreover, it was also noted that sustainable cultivation leads to an increase of the levels of these substances, as well as found with organic procedures [80].

Similar results, i.e. high levels of polyphenols in food of biological origin, were observed in tomatoes [81], where about $5.9 \mathrm{mg}$ of total flavonoids/g in conventional fruits against $65 \mathrm{mg} / \mathrm{g}$ in organic ones, were determined. Other authors, analyzing statistical differences between organic and conventional vegetables, found higher concentrations of polyphenols in organic broccoli (Brassica oleracea var. Italica), potatoes (Solanum tuberosum), carrots (Daucus carota) and cabbages (Brassica oleracea var. Capitata) [82]. It was found [83] the same trend in spinach (Spinacea oleracea), onion (Allium cepa), and pumpkin (Curcubita pepo). Observations showed also the strong influence of environmental conditions, growing season and genotypes in the concentration of these phytochemicals within the same specie [84].

The use of synthetic fertilizers is common in conventional cultivation practice, which guarantees a higher bioavailable source of nitrogen, accelerating plant development and energy for the synthesis of secondary metabolites. However, the absence of synthetic pesticides results in a plant exposure to stressful situations due to insect attack, leading to an enhancement of natural defenses, such as phenolic compounds [85] [86]. Both hypotheses would result in foods with higher antioxidant capacity, as a consequence of the higher polyphenol composition.

Organic growing system promotes the biodiversity, and the elimination of pesticides can stress plants [87]. In response, plants can increase their content of defense molecules and important phytochemicals, such as phenolic compounds. It has been hypothesized that an increase in environmental stresses promotes the activity of phenylalanine ammonia lyase (PAL) [88]. Thus, organic production techniques may cause elevated levels of plant secondary metabolites, such as the increase of polyphenols found in lettuce (Lactuca sativa L. cv. Kalura and Red Sails), collards (Brassica oleracea L. cv. Top Bunch), and Chinese cabbage (Brassica rapa L. cv. Mei Qing) [88].

Several factors may induce an increase of polyphenols in plants, such as stress inducers, which can be represented by high or low light intensities, extreme temperatures, and ionizing radiations [89]-[91]. Some researchers have shown that wounding increases the antioxidant capacity of lettuce (Lactuca sativa) [92] and purple-flesh potatoes [89].

Several polyphenols may function as the defense materials against biotic (e.g., fungi, bacteria and insects) and abiotic (e.g., drought, metals and UV) stresses and their content in plant tissues may change in response to stressing conditions [93] [94]. Among defense substances, phytoalexins are secondary metabolites produced de novo by plants in response to stresses, whereas phytoanticipins are classified as constitutive metabolites with defensive roles [95] demonstrate that a limited drought stress treatment enhances significantly the polyphenol contents in part of the root mass of leafy vegetables, without affecting plant growth [96]. In studies on the response of different tomato varieties to water stress [97], a decrease in the rate of shikimate pathway (DAHP synthase, shikimate dehydrogenase, phenylalanine ammonium lyase, cinnamate 4-hydroxylase, 4-coumarate CoA ligase) and, as a consequence of phenolic compounds (caffeoylquinic acid derivatives, quercetin and kaempferol) were observed in sensitive cultivars. While, in tolerant cultivars an increase of flavonoid and phenylpropanoid synthesis and a decrease in degradation-related enzymes, were documented.

Alternatively, moderate salinity can induce an increase of polyphenol content in plants, such as in Mentha pulegium [98]. This could be interesting for specific cultivation areas. However, further studies should be carried out to verify the response of different vegetables to salinity stress.

Some studies showed the influence of fertilization, light and temperature, on polyphenol content of tomato (Solanum lycopersicum, cv. Suzanne). Plants were subjected to N depletion, during 4 - 8 days, resulting in enhanced levels of flavonoids and caffeoyl derivatives. Anthocyanin levels showed a pronounced increase at the lowering of growth temperature, from $24^{\circ} \mathrm{C}$ to $12^{\circ} \mathrm{C}$. Flavonol levels increased with light intensity, from 100 $\mu$ lum $\cdot \mathrm{m}^{-2} \cdot \mathrm{s}^{-1}$ to $200 \mu \mathrm{lum} \cdot \mathrm{m}^{-2} \cdot \mathrm{s}^{-1} \mathrm{PAR}$. Synergistic effects of the various environmental factors on tomato polyphenol content were observed. As an example, the increase in quercetin content in response to low temperatures was only found under $\mathrm{N}$ depletion conditions, and at the highest light intensity [99].

Anthracnose causes extensive pre- and post-harvest damage in fruits and vegetables. In order to characterize the defense properties of polyphenols, their content in pepper (Capsicum annuum L. cv. Chelsea (yellow bell pepper)) inoculated with C. gloeosporioides, was studied [100]. It was observed the de novo synthesis of $N$ caffeoyl putrescine and caffeoyl $O$-hexoside, which appeared to act as phytoalexins. While feruloyl $O$-glucoside, kaempferol $O$-pentosyldihexoside and dihydroxyflavone $O$-hexoside was constitutively formed, as phytoantici- 
pins. Thus, this study showed that infestation by microorganisms, inducing anthracnose, can lead to the formation of phenolic compounds.

The increase of food polyphenol content can be interesting in order to improve human health, because consumers will absorb increasing amount of these compounds. However, it is mandatory to check post-harvest quality of vegetables and fruits, in order to evaluate product changes upon storage. Generally, antioxidant activity and phenolic concentration increase during storage [101]. Although few studies reported on constant or decreasing polyphenol levels during storage [101] [102], the variation of flavonol and anthocyanin content was measured by Rodrigues et al. [103] in red and white onion bulbs (in 2005 and 2006 harvests), during 7 months storage under refrigerated and traditional bulk storage in the field. Total flavonols increased up to $64 \%$ after 7 months of storage. This increase was especially important during the first 3 months storage (58\% increase). In red onions, containing the highest concentrations of flavonols, bulbs stored in the field reached higher levels of flavonoids (64\%) than refrigerated ones (40\%).

Temperature control could be useful in order to increase polyphenol content in fruits, as it was observed on apples, where cold storage increased the polyphenol content [104]. Thus, the meteorological conditions affect the content and quality of polyphenols such as flavonoids in plants. Some studies have shown this effect, as observed in landrace varieties of onion (Allium cepa L.), where the authors founded the total and individual flavonoids levels varied significantly among seasons, with higher levels in 2005, a very dry and hot season [105].

Thus, the control of biotic and abiotic stresses, such as temperature, light intensity, herbivory and microbial attack, may be used to modulate plant defense mechanisms, triggering many complex biochemical processes [106].

\section{Actions of Phenolic Compounds on Human Health}

Phenolic compounds appear to influence the quality of fruits, contributing to their organoleptic and sensorial quality, in addition to improving fruit nutritional value [107]. As an example, strawberry (Fragaria $\times$ ananassa Duch) contains high levels of polyphenols, leading to a high antioxidant activity. This fruit is consumed in fresh form, in processed food products, and as extracts for dietary supplements [108]. Different phenolic compounds from strawberry extracts: cyanidin-3-glucoside, pelargonidin, pelargonidin-3-glucoside, pelargonidin-3-rutinoside, kaempferol, quercetin, kaempferol-3-(6'-coumaroyl) glucoside, 3,4,5-trihydroxyphenyl-acrylic acid, glucose ester of (E)-p-coumaric acid, and ellagic acid, were evaluated for antioxidant and antiproliferative activities on human cancer cell. Authors verified that crude strawberry extracts, and purified compounds, inhibited the growth of human oral (CAL-27, KB), colon (HT29, HCT-116), and prostate (LNCaP, DU145) cancer cells in a dose dependent manner with various degrees of potency.

Other fruits were also tested in terms of anticancer activity regarding the content and type of polyphenols. The extracts of six popularly consumed berries were evaluated for their phenolic constituents: blackberry (Rubus sp), black raspberry (Rubus occidentalis), blueberry (Vaccinium corumbosum var. Jersey), cranberry (V. macrocarpon var. Early Black), red raspberry (Rubus idaeus) and strawberry [109]. It was observed that the major classes of berry phenolics were anthocyanins, flavonols, flavanols, ellagitannins, gallotannins, proanthocyanidins, and phenolic acids. Black raspberry and strawberry extracts showed the most significant pro-apoptotic effects against tested cell lines, and preliminary data were provided about the ability of these compounds to inhibit the growth and to induce apoptosis of different human cancer cell lines in vitro.

\section{Ingestion and Content of Phenolic Compounds in Fruits and Vegetables}

Several studies have been carried out about the consumption of phenolic compounds, as well as on the contribution of these compounds to the diet. In the USA, the average per capita consumption of phenolic compounds from fruits and vegetables is in the range $200-300 \mathrm{mg} /$ day [110] [111]. Furthermore, Chun et al. [112] pointed out that in the USA, the daily intake of phenolics, flavonoids and antioxidants from fruits and vegetables was estimated to be $450 \mathrm{mg}$ GAE (gallic acid equivalent), $103 \mathrm{mg}$ catechin equivalents and $591 \mathrm{mg}$ VCE (vitamin C equivalents), respectively. Authors attributed these differences, possibly, to the methods used for extraction and to the determination method for foods analyses. In France, the fruit polyphenol intake is around $219 \mathrm{mg}$ (men), $193 \mathrm{mg}$ (women), while for vegetable polyphenols, the value is $78 \mathrm{mg}$ (men) and $67 \mathrm{mg}$ (women) [113]. It was estimated that the dietary intake of flavonoids for the Brazilian population is in the range $60-106 \mathrm{mg} / \mathrm{day}$, of 
which 70\% from oranges, $8.9 \%$ from lettuce and 5.8\% from onions [114]. In a study carried out on the population of Fortaleza (Ceará, Brazil), the total phenolic content determined in samples of fruit salad (banana, papaya, guava, mango and pineapple) ranged from 27 to $97 \mathrm{mg} / 100 \mathrm{~mL}$ [115]. Faller \& Fialho [82] studied the availability of polyphenols in fruits and vegetables consumed in Brazil, and determined the following content: 85 $\mathrm{mg} / 100 \mathrm{~g}$ for pineapple, $215.7 \mathrm{mg} / 100 \mathrm{~g}$ for banana, $15.3 \mathrm{mg} / 100 \mathrm{~g}$ for papaya and $110.5 \mathrm{mg} / 100 \mathrm{~g}$ for mango. In peaches, the phenolic content varies according to the cultivar, from $53 \mathrm{mg}$ gallic acid/100g for Douradão pulp, to $141 \mathrm{mg}$ gallic acid/100g for "Big-Aurora" pulp [116]. Thus, the variety of the vegetable consumed dramatically the content of phenolic compounds ingested by humans.

It should be mentioned that the determination of the apparent polyphenol content can be influenced by the extraction method. The amount of total polyphenolics varies among the types of extracts: aqueous or hydroalcoholic, as reported for acerola (Malpighia emarginata) $(835.25 \mathrm{mg} / 100 \mathrm{~mL}$ by acqueous extraction and 449.63 $\mathrm{mg} / 100 \mathrm{~mL}$ by hydroalcoholic extraction), bacuri (Platonia insignis Mart.) $(10.35 \mathrm{mg} / 100 \mathrm{~mL}$ by acqueous extraction and $7.23 \mathrm{mg} / 100 \mathrm{~mL}$ by hydroalcoholic extraction), cashew (Anacardium occidentale) (201.61 mg/ $100 \mathrm{~mL}$ by acqueous extraction and $165.07 \mathrm{mg} / 100 \mathrm{~mL}$ by hydroalcoholic extraction), guava (Psidium guajava) (104.76 mg/100mL by acqueous extractionand $20.2 \mathrm{mg} / 100 \mathrm{~mL}$ by hydroalcoholic extraction) and tamarind (Tamarindus indica L.) (23.57 mg/100 mL by acqueous extraction and $23.35 \mathrm{mg} / 100 \mathrm{~mL}$ by hydroalcoholic extraction) [117].

Since vegetables and fruits are good sources of polyphenols, their consumption is essential for health. According to the recommendation of the Food and Agriculture Organization (FAO), the consumption of fruits and vegetables should be about $400 \mathrm{~g}$ per day. Thus, the increased consumption of fruits and vegetables can lead to an increase in the supply of polyphenols. In São Paulo city (Brazil), the consumption of these products is higher among women, being twice as high when compared to men [118], differently, from what reported by Brat et al. [113] in France (see above). Probably, this variation can be attributed to the type of plant in the country, and even to cultural factors and purchasing power.

\section{Thermal Processing of Fruits and Vegetables and Phenolic Content}

Many fruits and vegetables are not eaten as raw. Some undergo special treatments, such as heating (jelly), freezing (fruit pulp), among others. Some studies showed that these treatments, used mainly by industry, tend to change the content of polyphenols. The use of high temperature, frying in particular, induces a decrease in flavonoid content in artichoke (Cynara scolymus) [119]. Moreover, Yamaguchi et al. [120] found no loss of phenolic compounds even after 15 minutes of thermal processing on burdock (Arctium lappa) and lettuce (Lactuca sativa) after one minute cooking in water, whereas in broccoli, the polyphenol content remained constant after 15 minutes processing. A decrease in the content of these substances in beans (Phaseolus vulgaris) after baking was observed [121]. Spinach and potato when grilled, presented a reduced antioxidant capacity and total phenolic content [122]. Similar results were found in cooked carrots, tomatoes, and eggplant (Solanum melongena); broccoli lost about $97 \%$ of flavonoids and $74 \%$ of synaptic acid derivatives upon the same treatment [123]. Moreover, after cooking in water, chlorogenic acid in carrots and phenolic content in beans increased significantly, however, no differences were observed in caffeic and chlorogenic acid content in potatoes. According to Barroga et al. [124], this effect can be due to the leaching of phenols, which can occur during cooking in water. This process was found to depend on temperature. Other authors also observed a loss of phenolic compounds in cooked foods, such as in carrots [125].

It was reported that some food processing procedures can increase the content of phenolic compounds, compared with raw vegetables [126]-[128]. In this case, the effect would be the improvement of the extraction of phenolic compounds by increased temperature, and not only by cellular disruption [129].

Moreover, a review about the consumption of raw and cooked vegetables and about the correlation among food treatment and some types of cancer, was performed. Possible effects may include changes in availability of some nutrients, destruction of oxidative enzymes, and alteration of the structure and digestibility of food [130].

The consumption of fruit pulp is widespread, due to the ease of preparation and seasonality. Frozen pulps are commonly used both for domestic consumption and industrial purposes. Some studies indicated that good conservation of polyphenol contents occurs upon freezing. Thus, this procedure appears an effective way for preserving antioxidant properties of fruits. Although, this process induces an irreversible physical destruction of cell walls and protoplasts, causing a damage to fruit texture and therefore a loss of quality [131]. The freezing 
process slightly affects the content of extracted ellagic acid, total polyphenols and vitamin C, in raspberry cultivars [132]. Authors verified that, at the end of long-term frozen storage (12 months), no significant changes in total polyphenol content was observed, but a significant decrease (14\% - 21\%) in ellagic acid was determined.

Several studies on the effects of fruit pulp extracts on cancer cells have been carried out, often with promising results. A study on cell lines isolated from SCC human oral tumor cells was performed with the aim to investigate on the effects of a freeze-dried black raspberry ethanol extract on cellular growth, cell proliferation, induction of angiogenesis, and production of reactive species. The results showed that the berry extract suppressed cell proliferation, without perturbing viability. It inhibited the expression of an angiogenic cytokine, the vascular endothelial growth factor, and induced cell apoptosis and terminal differentiation [133].

\section{Absorption of Phenolic Compounds}

Although there are a lot of fruits and vegetables with high content of phenolic compounds, and even their polyphenol content is maintained upon processing, we must highlight the question of body absorption, since it depend on bioavailability. Some polyphenols, such as quercetin, myricetin and kaempferol, may be absorbed by intestine. However, often this represents only a tiny fraction [134]. Glycosylated forms and polyphenol mixtures are generally absorbed in the intestine [9] [10] and some molecules, such as isoflavones and gallic acid, are better absorbed than others. Their relatively high absorption efficiency is followed by flavonones (catechins and quercetin glycosides), and then by proanthocyanidins, anthocyanins, and catechins gallate, but with different kinetics [135]. Most polyphenols are quickly excreted within the $24 \mathrm{~h}$ following their ingestion [135] [136]. Some studies showed that it is possible to detect polyphenols in urine and in plasma after ingestion of a polyphenol rich food [137] [138].

Moreover, higher doses, flavonoids may act as mutagens, pro-oxidants that generate free radicals, and as inhibitors of key enzymes involved in hormone metabolism. Thus, in high doses, the adverse effects of flavonoids may outweigh their beneficial ones, and caution should be exercised in ingesting them at levels above that which would be obtained from a typical vegetarian diet [139]. About choccolate consume, a rich flavonoid food, the results have shown effects of flavonoid-rich foods in raising plasma total antioxidant capacities (TAC) in humans and one must be cautious is that many such foods can increase plasma uric acid levels, and urate is detected by several TAC assays urate may be a risk factor for some diseases, the alleged antioxidant benefit may not be what it seems [140]. According [141], "the dietary polyphenols are typical xenobiotics, metabolized as such and rapidly removed from the circulation. They may be beneficial in the gut in the correct amounts. But too much may not be good and thus, the author suggests that one should be content with eating a good diet for now".

Although studies show that consumption is beneficial, and others show that care is needed in the intake of these substances, further studies should be conducted. However, the consumption of foods with antioxidant potential has received much attention and probably should have more benefits than harm. Otherwise, studies regarding the use of these substances have already adopted another direction, ie, to prevent the intake of polyphenols.

\section{Conclusion}

The present review emphasizes the importance of knowing the content and the quality of polyphenols present in fruits and vegetables. We illustrate the complexity of the study of polyphenol effect on human health. It is difficult to evaluate the physiological effects of specific natural phenolic antioxidants, since a large number of differrent compounds may occur in a single food, and their fate in vivo can hardly be measured. Other detailed agronomical, biochemical and chemical research must be performed in order to elucidate the role of these substances, from the original plant to human beings.

\section{References}

[1] Harbone, J.B. and Williams, C. (2000) Advances in Flavonoid Research Since 1992. Phytochemistry, 55, 481-504. http://dx.doi.org/10.1016/S0031-9422(00)00235-1

[2] Santos-Buelga, C. and Sacalbert, A. (2000) Proanthocyanidins and Tannin-Like Compounds-Nature, Occurrence, Dietary Intake and Effects on Nutrition and Health. Journal of the Science and Food Agriculture, 80, 1094-1117. http://dx.doi.org/10.1002/(SICI)1097-0010(20000515)80:7<1094::AID-JSFA569>3.0.CO;2-1 
[3] King, A. and Young, G. (1999) Characteristics and Occurrence of Phenolic Phytochemicals. Journal of the American Dietetic Association, 99, 213-218. http://dx.doi.org/10.1016/S0002-8223(99)00051-6

[4] Del Rio, D., Rodriguez-Mateos, A., Spencer, J.P.E., Tognolini, M., Borges, G. and Crozier, A. (2012) Dietary (poly)phenolics in Human Health: Structures, Bioavailability, and Evidence of Protective Effects against Chronic Diseases. Antioxidants \& Redox Signaling, 18, 1-73. http://dx.doi.org/10.1089/ars.2012.4581

[5] Rommel, A. and Wrolstad, R.E. (1993) Ellagic Acid Content of Red Raspberry Juice as Influenced by Cultivar, Processing, and Environmental Factors. Journal of Agriculture and Food Chemistry, 41, 1951-1960. http://dx.doi.org/10.1021/jf00035a026

[6] Paszkiewicz, M., Budzynska, A., Rozalska, B. and Sadowska, B. (2012) The Immunomodulatory Role of Plant Polyphenols. Postepy Higieny i Medycyny Doswiadczalnej, 66, 637-646. http://dx.doi.org/10.5604/17322693.1009908

[7] Hertog, M.L.G., Hollman, P.C.H. and Katan, M.B. (1992) Content of Potentially Anticarcinogenic Flavonoids of 28 Vegetables and 9 Fruits Commonly Consumed in the Netherlands. Journal of Agriculture and Food Chemistry, 40, 2379-2383. http://dx.doi.org/10.1021/jf00024a011

[8] Yao, L.H., Jiang, Y.M., Shi, J., Tomás-Barberán, F.A., Datta, N. and Singanusong, R. (2004) Flavonoids in Food and Their Health Benefits. Plant Foods for Human Nutrition, 59, 113-122. http://dx.doi.org/10.1007/s11130-004-0049-7

[9] Gee, J.M., Du Pont, M.S., Rhodes, M.J. and Johnson, I.T. (1999) Quercetin Glucosides Interact with the Intestinal Glucose Transport Pathway. Free Radical Biology and Medicine, 25, 19-25. http://dx.doi.org/10.1016/S0891-5849(98)00020-3

[10] Gee, A.J., Du Pont, S.J., Johnson, M.S. and Williamson, G. (2003) Absorption of Quercetin-3-Glucoside and Quercetin-4'-Glucoside in the Rat Small Intestine: The Role of Lactase Phlorizin Hydrolase and the Sodium-Dependent Glucose Transporter. Biochemical Pharmacology, 65, 1199-1206. http://dx.doi.org/10.1016/S0006-2952(03)00039-X

[11] Traxler, P., Green, J., Mett, H., Séquin, U. and Furet, P. (1999) Use of a Pharmacophore Model for the Design of Egfr Tyrosine Kinase Inhibitors: Isoflavones and 3-Phenyl-4(1h)-quinolones. Journal of Medicinal Chemistry, 42, 10181026. http://dx.doi.org/10.1021/jm9805510

[12] Williamson, G. and Carughi, A. (2010) Polyphenol Content and Health Benefits of Raisins. Nutrition Research, 30, 511-519. http://dx.doi.org/10.1016/j.nutres.2010.07.005

[13] Okubo, T., Yokoyama, Y., Kano, K. and Cell, I. (2003) Death Induced by the Phenolic Antioxidant Tert-Butylhydroquinone and Its Metabolite Tert-Butylquinone in Human Monocytic Leukemia U937 Cells. Food and Chemical Toxicology, 41, 679-688. http://dx.doi.org/10.1016/S0278-6915(03)00002-4

[14] Dolatabadi, J.E.N. and Kashanian, S. (2010) A Review on DNA Interaction with Synthetic Phenolic Food Additives. Food Research International, 43, 1223-1230. http://dx.doi.org/10.1016/j.foodres.2010.03.026

[15] Pereira, C.A.M. and Maia, J.F. (2007) Study of the Antioxidant Activity and Essential Oil from Wild Basil (Ocimum gratissimum L.) Leaf. Ciência e Tecnoogia de Alimentos, 27, 624-632. http://dx.doi.org/10.1590/S0101-20612007000300030

[16] Rice-Evans, C.A., Miller, N.J. and Paganga, G. (1997) Antioxidant Properties of Phenolic Compounds. Trends in Plant Science, 2, 152-159. http://dx.doi.org/10.1016/S1360-1385(97)01018-2

[17] Scandalios, J.G. (2005) Oxidative Stress: Molecular Perception and Transduction of Signals Triggering Antioxidant Gene Defenses. Brazilian Journal of Medical and Biological Research, 38, 995-1014. http://dx.doi.org/10.1590/S0100-879X2005000700003

[18] Wiseman, H. and Halliwell, B. (1996) Damage to DNA by Reactive Oxygen and Nitrogen Species: Role in Inflammatory Disease and Progression to Cancer. Biochemical Journal, 313, 17-29.

[19] Halliwell, B. (2001) Role of Free Radicals in the Neurodegenerative Diseases. Drugs \& Aging, 18, 685-716. http://dx.doi.org/10.2165/00002512-200118090-00004

[20] Linares, E., Mortara, R.A., Santos, C.X., Yamada, A.T. and Augusto, O. (2001) Role of Peroxynitrite in Macrophage Microbicidal Mechanisms in Vivo Revealed by Protein Nitration and Hydroxylation. Free Radical Biology and Medicine, 30, 1234-1242. http://dx.doi.org/10.1016/S0891-5849(01)00516-0

[21] Cerqueira, F.M., de Medeiros, M.H.G. and Augusto, O. (2007) Antioxidantes dietéticos: Controvérsias e perspectivas. Química Nova, 30, 441-449. http://dx.doi.org/10.1590/S0100-40422007000200036

[22] Halliwell, B., Aeschbach, R., Löliger, J. and Aruoma, O.I. (1995) The Characterization on Antioxidants. Food and Chemical Toxicology, 33, 601-617. http://dx.doi.org/10.1016/0278-6915(95)00024-V

[23] Mallick, N. and Mohn, F.H. (2000) Reactive Oxygen Species: Response of Algal Cells. Journal of Plant Physiology, 157, 183-193. http://dx.doi.org/10.1016/S0176-1617(00)80189-3

[24] Xia, J., Allenbrand, B. and Sun, G.Y. (1998) Dietary Supplementation of Grape Polyphenols and Chronic Ethanol Administration on LDL Oxidation and Platelet Function in Rats. Life Sciences, 63, 383-390. 
http://dx.doi.org/10.1016/S0024-3205(98)00286-0

[25] de Lorgeril, M., Salen, P., Martin, J.L., Monjaud, I., Delaye, J. and Mamelle, N. (1999) Mediterranean Diet, Traditional Risk Factors, and the Rate of Cardiovascular Complications after Myocardial Infarction: Final Report of the Lyon Diet Heart Study. Circulation, 99, 779-785. http://dx.doi.org/10.1161/01.CIR.99.6.779

[26] Ferreira, A.L.A., Salvadori, D.M., Nascimento, M.C., Rocha, N.S., Correa, C.R., Pereira, E.J., Matsubara, L.S., Matsubara, B.B. and Ladeira, M.S.P. (2007) Tomato-Oleoresin Supplement Prevents Doxorubicin-Induced Cardiac Myocyte Oxidative DNA Damage in Rats. Mutation Research/ Genetic Toxicology and Environmental Mutagenisis, 631, 26-35. http://dx.doi.org/10.1016/j.mrgentox.2007.04.003

[27] Yeum, K.J., Russell, R.M., Krinsky, N.I. and Aldini, G. (2004) Biomarkers of Antioxidant Capacity in the Hydrophilic and Lipophilic Compartments of Human Plasma. Arcives of Biochemistry and Biophysics, 430, 97-103. http://dx.doi.org/10.1016/j.abb.2004.03.006

[28] Ralser, M., Wamelink, M.M., Kowald, A., Gerisch, B., Heeren, G., Struys, E.A., Klipp, E., Jakobs, C., Breitenbach, M., Lehrach, H. and Krobitsch, S. (2007) Dynamic Rerouting of the Carbohydrate Flux Is Key to Counteracting Oxidative Stress. Journal of Biology, 6, 10. http://dx.doi.org/10.1186/jbiol61

[29] Grant, C.M. (2008) Metabolic Reconfiguration Is a Regulated Response to Oxidative Stress. Journal of Biology, 7, 1. http://dx.doi.org/10.1186/jbiol63

[30] Poli, G., Schaur, R.J., Siems, W.G. and Leonarduzzi, G. (2008) 4-Hydroxynonenal: A Membrane Lipid Oxidation Product of Medicinal Interest. Medicinal Research Reviews, 28, 569-631. http://dx.doi.org/10.1002/med.20117

[31] Aldini, G., Dalle-Donne, I., Facino, R.M., Milzani, A. and Carini, M. (2007) Intervention Strategies to Inhibit Protein Carbonylation by Lipoxidation-Derived Reactive Carbonyls. Medicinal Research Review, 27, 817-868. http://dx.doi.org/10.1002/med.20073

[32] Bierhaus, A., Hofmann, M.A., Ziegler, R. and Nawroth, P.P. (1998) AGEs and Their Interaction with AGE-Receptors in Vascular Disease and Diabetes Mellitus. I. The AGE Concept. Cardiovascular Research, 37, 586-600. http://dx.doi.org/10.1016/S0008-6363(97)00233-2

[33] Brownlee, M. (2001) Review Article Biochemistry and Molecular Cell Biology of Diabetic Complications. Nature, 414, 813-820. http://dx.doi.org/10.1038/414813a

[34] Brownlee, M. (2005) The Pathobiology of Diabetic Complications: A Unifying Mechanism. Diabetes, 54, $1615-1625$. http://dx.doi.org/10.2337/diabetes.54.6.1615

[35] Bierhaus, A., Illmer, T., Kasper, M., Luther, T., Quehenberger, P., Tritschler, H., Wahl, P., Ziegler, R., Müller, M. and Nawroth, P.P. (1997) Advanced Glycation End Product (AGE)-Mediated Induction of Tissue Factor in Cultured Endothelial Cells Is Dependent on RAGE. Circulation, 96, 2262-2271. http://dx.doi.org/10.1161/01.CIR.96.7.2262

[36] Harcourt, B.E., Sourris, K.C., Coughlan, M.T., Walker, K.Z., Dougherty, S.L., Andrikopoulos, S., Morley, A.L., Thallas-Bonke, V., Chand, V., Penfold, S.A., de Courten, M.P.J., Thomas, M.C., Kingwell, B.A., Bierhaus, A., Cooper, M. E., de Courten, B. and Forbes, J.M. (2011) Targeted Reduction of Advanced Glycation Improves Renal Function in Obesity. Kidney International, 80, 190-198. http://dx.doi.org/10.1038/ki.2011.57

[37] Yamagishi, A., Kunisawa, T., Nagashima, M., Takahata, O. and Iwasaki, H. (2009) Clinical Usefulness of Continuous Cardiac Output Measurement: PulseCO. Masui. The Japanese Journal of Anesthesiology, 58, 422-425.

[38] Rodiño-Janeiro, B.K., Salgado-Somoza, A., Tejeira-Fernandez, E., González-Juanatey, J.R., Álvarez, E. and Eiras, S. (2011) Receptor for Advanced Glycation End-Products Expression in Subcutaneous Adipose Tissue Is Related to Coronary Artery Disease. European Journal of Endocrinology, 164, 529-537. http://dx.doi.org/10.1530/EJE-10-0904

[39] Liu, C., Wang, X.D., Bronson, R.T., Smith D.E., Krinsky, N.I. and Russell, R.M. (2000) Effects of Physiological Versus Pharmacological Beta-Carotene Supplementation on Cell Proliferation and Histopathological Changes in the Lungs of Cigarette Smoke-Exposed Ferrets. Carcinogenesis, 21, 2245-2253. http://dx.doi.org/10.1093/carcin/21.12.2245

[40] Neuhouser, M.L., Miller, D.L., Kristal, A.R., Barnett, M.J. and Cheskin, L.J. (2002) Diet and Exercise Habits of Patients with Diabetes, Dyslipidemia, Cardiovascular Disease or Hypertension. Journal of the American College of Nutrition, 21, 394-401. http://dx.doi.org/10.1080/07315724.2002.10719241

[41] Hung, C.F., Huang, T.F., Chen, B.H., Shieh, J.M., Wu, P.H. and Wu, W.B. (2008) Lycopene Inhibits TNF-Alpha-Induced Endothelial ICAM-1 Expression and Monocyte-Endothelial Adhesion. European Journal of Pharmacology, 586, 275-282. http://dx.doi.org/10.1016/j.ejphar.2008.03.001

[42] Visioli, F., De La Lastra, C.A., Andres-Lacueva, C., Aviram, M., Calhau, C., Cassano, A., D’Archivio, M., Faria, A., Favé, G., Fogliano, V., Llorach, R., Vitagione, P., Zoratti, M. and Edeas, M. (2011) Polyphenols and Human Health: A Prospectus. Critical Reviews in Food Science and Nutrition, 51, 524-546. http://dx.doi.org/10.1080/10408391003698677

[43] Ahn, J., Cho, I., Kim, S., Kwon, D. and Ha, T. (2008) Dietary Resveratrol Alters Lipid Metabolism-Related Gene Expression of Mice on an Atherogenic Diet. Journal of Hepatology, 49, 1019-1028. 
http://dx.doi.org/10.1016/j.jhep.2008.08.012

[44] Szkudelska, K., Nogowski, L. and Szkudelski, T. (2009) Resveratrol, a Naturally Occurring Diphenolic Compound, Affects Lipogenesis, Lipolysis and the Antilipolytic Action of Insulin in Isolated Rat Adipocytes. The Journal of Steroid Biochemistry and Molecular Biology, 113, 17-24. http://dx.doi.org/10.1016/j.jsbmb.2008.11.001

[45] Li, R.W., Douglas, T.D., Maiyoh, G.K., Adeli, K. and Theriault, A.G. (2006) Green Tea Leaf Extract Improves Lipid and Glucose Homeostasis in a Fructose-Fed Insulin-Resistant Hamster Model. Journal of Ethnopharmacology, 104, 24-31. http://dx.doi.org/10.1016/j.jep.2005.08.045

[46] Bose, M., Lambert, J.D., Ju, J., Reuhl, K.R., Shapses, S.A. and Yang, C.S. (2008) The Major Green Tea Polyphenol, (-)-Epigallocatechin-3-Gallate, Inhibits Obesity, Metabolic Syndrome, and Fatty Liver Disease in High-Fat-Fed Mice. The Journal of Nutrition, 138, 1677-1683.

[47] Potenza, M.A., Marasciulo, F.L., Tarquinio, M., Tiravanti, E., Colantuono, G., Federici, A., Kim, J., Quon, M.J. and Montagnani, M. (2007) EGCG, a Green Tea Polyphenol, Improves Endothelial Function and Insulin Sensitivity, Reduces Blood Pressure, and Protects against Myocardial I/R Injury in SHR. American Journal of Physiology, Endocrinology and Metabolism, 292, No. E1378-E1387, , http://dx.doi.org/10.1152/ajpendo.00698.2006

[48] Ejaz, A., Wu, D., Kwan, P. and Meydani, M. (2009) Curcumin Inhibits Adipogenesis in ${ }_{3} \mathrm{~T}_{3}$-L1 Adipocytes and Angiogenesis and Obesity in $\mathrm{C}_{57} / \mathrm{BL}$ Mice ${ }^{1-3}$. The Journal of Nutrition and Disease, 139, 919-925. http://dx.doi.org/10.3945/jn.108.100966

[49] Egert, S., Bosy-Westphal, A., Seiberl, J., Kürbitz, C., Settler, U., Plachta-Danielzik, S., Wagner, A.E., Frank, J., Shrezenmeir, J., Rimbach, G., Wolffram, S. and Müller, M.J. (2009) Quercetin Reduces Systolic Blood Pressure and Plasma Oxidised Low-Density Lipoprotein Concentrations in Overweight Subjects with a High-Cardiovascular Disease Risk Phenotype: A Double-Blinded, Placebo-Controlled Cross-Over Study. British Journal of Nutrition, 102, 10651074. http://dx.doi.org/10.1017/S0007114509359127

[50] Egert, S., Boesch-Saadatmandi, C., Wolffram, S., Rimbach, G. and Müller, M.J. (2010) Serum Lipid and Blood Pressure Responses to Quercetin Vary in Overweight Patients by Apolipoprotein E Genotype ${ }^{1,2}$. The Journal of Nutricion, 140, 278-284. http://dx.doi.org/10.3945/jn.109.117655

[51] Storz, P. (2006) Reactive Oxygen Species-Mediated Mitochondria-to-Nucleus Signaling: A Key to Aging and RadicalCaused Diseases. Science Signaling, 2006, 1-7. http://dx.doi.org/10.1126/stke.3322006re3

[52] Cadenas, E. and Davies, K.J.A. (2000) Mitocondrial Free Radical Generation, Oxidative Stress, and Aging. Free Radical Biology and Medicine, 29, 222-230. http://dx.doi.org/10.1016/S0891-5849(00)00317-8

[53] Andújar, I., Recio, M.C., Giner, R.M. and Ríos, J.L. (2012) Cocoa Polyphenols and Their Potential Benefits for Human Health. Oxidative Medicine and Cellular Longevity, 2012, Article ID 906252. http://dx.doi.org/10.1155/2012/906252

[54] Hogan, S., Canning, C., Sun, S., Sun, X. and Zhou, K. (2010) Effects of Grape Pomace Antioxidant Extract on Oxidative Stress and Inflammation in Diet Induced Obese Mice. Journal of Agricultural and Food Chemistry, 58, 1125011256. http://dx.doi.org/10.1021/jf102759e

[55] Alappat, L. and Awad, A.B. (2010) Curcumin and Obesity: Evidence and Mechanisms. Nutrition Reviews, 68, 729-738. http://dx.doi.org/10.1111/j.1753-4887.2010.00341.x

[56] Govindarajan, V.S. and Stahl, W.H. (1980) Turmeric-Chemistry, Technology and Quality. CRC Critical Reviews in Food Science and Nutrition, 12, 199-301. http://dx.doi.org/10.1080/10408398009527278

[57] Jagota, A. and Reddy, M. (2007) The Effect of Curcumin on Ethanol Induced Changes in Suprachiasmatic Nucleus (SCN) and Pineal. Cellular and Molecular Neurobiology, 27, 997-1006. http://dx.doi.org/10.1007/s10571-007-9203-8

[58] Lin, Y., Lin, C., Chi, C. and Huang, Y. (2009) Study on Antifibrotic Effects of Curcumin in Rat Hepatic Stellate Cells. Phytotherapy Research, 23, 927-932. http://dx.doi.org/10.1002/ptr.2764

[59] Bierhaus, A., Zhang, Y., Quehenberger, P., Luther, T., Haase, M., Muller, M., Mackman, N., Ziegle, R. and Nawroth, P.P. (1997) The Dietary Pigment Curcumin Reduces Endothelial Tissue Factor Gene Expression by Inhibiting Binding of AP-1 to the DNA and Activation of NF-Kappa B. Thrombosis and Haemostasis, 77, 772-782.

[60] Looker, A.C., Johnston Jr, C., Wahner, H.W., Dunn, W.L., Calvo, M.S., Harris, T.B., et al. (1995) Prevalence of Low Femoral Bone Density in Older U.S. Women from NHANES III. Journal of Bone and Mineral Research, 10, 796-802. http://dx.doi.org/10.1002/jbmr.5650100517

[61] Inada, M., Iwasak, K., Imai, C. and Hashimoto, S. (2010) Hyperpotassemia and Bradycardia in a Bedridden Elderly Woman with Selective Hypoaldosteronism Associated with Low Renin Activity. Internal Medicine, 49, 307-313. http://dx.doi.org/10.2169/internalmedicine.49.2416

[62] Syed, F.A. and Hoey, K.A. (2010) Integrative Physiology of the Aging Bone: Insights from Animal and Cellular Models. Annals of the New York Academy of Sciences, 1211, 95-106. http://dx.doi.org/10.1111/j.1749-6632.2010.05813.x

[63] Manolagas, S.C. (2010) From Estrogen-Centric to Aging and Oxidative Stress: A Revised Perspective of the Pathogenesis of Osteoporosis. Endocrine Reviews, 31, 266-300. http://dx.doi.org/10.1210/er.2009-0024 
[64] Valavanidis, A., Vlachogianni, T. and Fiotakis, C. (209) 8-Hydroxy-2'-deoxyguanosine (8-OHdG): A Critical Biomarker of Oxidative Stress and Carcinogenesis. Journal of Environmental Science and Health, Part C: Environmental Carcinogenesis and Ecotoxicology Reviews, 27, 120-139. http://dx.doi.org/10.1080/10590500902885684

[65] Pilger, A. and Rüdiger, H.W. (2006) 8-Hydroxy-2'-deoxyguanosine as a Marker of Oxidative DNA Damage Related to Occupational and Environmental Exposures. International Archives of Occupational and Environmental Health, 80, 115. http://dx.doi.org/10.1007/s00420-006-0106-7

[66] Shen, C.L., Cao, J.J., Dagda, R.Y., Tenner Jr., T.E., Chyu, M.C. and Yeh, J.K. (2011) Supplementation with Green Tea Polyphenols Improves Bone Microstructure and Quality in Aged, Orchidectomized Rats. Calcified Tissue Internacional, 88, 455-463. http://dx.doi.org/10.1007/s00223-011-9477-1

[67] Shen, C.L., Chyu, M.C., Yeh, J.K., Felton, C.K., Xu, K.T., Pence, B.C. and Wang, J.S. (2009) Green Tea Polyphenols and Tai Chi for Bone Health: Designing a Placebo-Controlled Randomized Trial. BMC Musculoskeletal Disorders, 10, 110. http://dx.doi.org/10.1186/1471-2474-10-110

[68] Yang, G., Shu, X.O., Li, H., Chow, W.H., Ji, B.T., Zhang, X., Gao, Y.T. and Zheng, W. (2007) Prospective Cohort Study of Green Tea Consumption and Colorectal Cancer Risk in Women. Cancer Epidemiology Biomarkers and Prevention, 16, 1219-1223. http://dx.doi.org/10.1158/1055-9965.EPI-07-0097

[69] Jochmann, N., Baumann, G. and Stangl, V. (2008) Green Tea and Cardiovascular Disease: From Molecular Targets towards Human Health. Current Opinion in Clinical Nutrition and Metabolic Care, 11, 758-765. http://dx.doi.org/10.1097/MCO.0b013e328314b68b

[70] Li, B., Hu, Q., Wang, H., Man, N., Ren, H., Wen, L., Nukina, N., Fei, E. and Wang, G. (2010) Omi/HtrA2 Is a Positive Regulator of Autophagy That Facilitates the Degradation of Mutant Proteins Involved in Neurodegenerative Diseases. Cell Death and Differentiation, 17, 1773-1784. http://dx.doi.org/10.1038/cdd.2010.55

[71] Qian, G., Xue, K., Tang, L., Wang, F., Song, X., Chyu, M.C., Pence, B.C., Shen, C.L. and Wang, J.S. (2012) Mitigation of Oxidative Damage by Green Tea Polyphenols and Tai Chi Exercise in Postmenopausal Women with Osteopenia. PloS ONE, 7, e48090. http://dx.doi.org/10.1371/journal.pone.0048090

[72] Link, A., Balaguer, F. and Goel, A. (2010) Cancer Chemoprevention by Dietary Polyphenols: Promising Role for Epigenetics. Biochemical Pharmacology, 80, 1771-1792. http://dx.doi.org/10.1016/j.bcp.2010.06.036

[73] de Melo, M.M., Nunes, L.C. and Leite, I.C.G. (2012) Relationship between Dietary Factors and Anthropometric and Gastrointestinal Tract Neoplasms: Investigations Done in Brazil. Revista Brasileira de Cancerologia, 58, 85-95.

[74] Neves, F.J., Koifman, R. and Mattos, I.E. (2006) Mortalidade por câncer de cólon e reto e consumo alimentar em capitais brasileiras selecionadas. Revista Brasileira de Epidemiologia, 9, 112-120. http://dx.doi.org/10.1590/S1415-790X2006000100014

[75] Bektic, J., Guggenberger, R., Eder, I.E., Pelzer, A.E., Berger, A.P., Bartsch, G. and Klocker, H. (2005) Molecular Effects of the Isoflavonoid Genistein in Prostate Cancer. Clinical Prostate Cancer, 4, 124-129. http://dx.doi.org/10.3816/CGC.2005.n.021

[76] Kurahashi, N., Sasazuki, S., Iwasaki, M., Inoue, M. and Tsugane, M.S. (2007) Green Tea Consumption and Prostate Cancer Risk in Japanese Men: A Prospective Study. America Journal of Epidemiology, 167, 71-77. http://dx.doi.org/10.1093/aje/kwm249

[77] Araújo, J.R., Gonçalves, P. and Martel, F. (2011) Chemopreventive Effect of Dietary Polyphenols in Colorectal Cancer Cell Lines. Nutricion Research, 31, 77-87. http://dx.doi.org/10.1016/j.nutres.2011.01.006

[78] Art, I.C.W. and Hollman, P.C.H. (2005) Polyphenols and Disease Risk in Epidemiological Studies. American Society for Clinical Nutrition, 81, 317S-325S.

[79] Pietta, P.G. (2000) Flavonoids as Antioxidants. Journal of Natural Products, 63, 1035-1042.

[80] Asami, D.K., Hong, Y.J., Barret, D.M. and Mitchell, A.E. (2003) Comparison of the Total Phenolic and Ascorbic Acid Content of Freeze-Dried and Air-Dried Marionberry, Strawberry, and Corn Grown Using Conventional, Organic, and Sustainable Agricultural Practices. Journal of Agricultural and Food Chemistry, 51, 1237-1241. http://dx.doi.org/10.1021/jf020635c

[81] Mitchell, A.E., Hong, Y.J., Koh, E., Barret, D.M., Bryant, D.E., Denison, R.F. and Kaffka, S. (2007) Ten-Year Comparison of the Influence of Organic and Conventional Crop Management Practices on the Content of Flavonoids in Tomatoes. Journal of Agricultural and Food Chemistry, 55, 6154-6159. http://dx.doi.org/10.1021/jf070344+

[82] Faller, A.L.K. and Fialho, E. (2009) Disponibilidad de polifenoles en frutas y hortalizas consumidas en Brasil. Revista de Saúde Pública, 43, 211-218 http://dx.doi.org/10.1590/S0034-89102009005000010

[83] Ren, H., Endo, H. and Hayashi, T. (2001) Antioxidative and Antimutagenic Activities and Polyphenol Content of Pesticide-Free and Organically Cultivated Green Vegetables Using Water-Soluble Chitosan as a Soil Modifier and Leaf Surface Spray. Journal Science of Food and Agriculture, 81, 1426-1432. http://dx.doi.org/10.1002/jsfa.955

[84] Anttonen, M.J. and Karjalainen, R.O. (2005) Environmental and Genetic Variation of Phenolic Compounds in Red 
Raspberry. Journal of Food Composition and Analysis, 18, 759-769. http://dx.doi.org/10.1016/j.jfca.2004.11.003

[85] Winter, C.K. and Davis, S.F. (2006) Organic Foods. Journal of Food Science, 71, 117-124. http://dx.doi.org/10.1111/j.1750-3841.2006.00196.x

[86] Woese, K., Lange, D., Boess, C. and Bögl, K.W. (1997) A Comparison of Organically and Conventionally Grown Foods-Results of a Review of the Relevant Literature. Journal of the Science of Food and Agriculture, 74, $281-293$. http://dx.doi.org/10.1002/(SICI)1097-0010(199707)74:3<281::AID-JSFA794>3.0.CO;2-Z

[87] NOP (National Organic Program) (2004) Fact Sheet. NOP Consumer Information United States Department of Agriculture, Washington DC, pp. 1.

[88] Young, J.E., Zhao, X., Carey, E.E., Welti, R., Yang, S.S and Wang, W. (2005) Phytochemical Phenolics in Organically Grown Vegetables. Molecular Nutrition \& Food Research, 49, 1136-1142. http://dx.doi.org/10.1002/mnfr.200500080

[89] Reyes, L.F. and Cisneros-Zevallos, L. (2003) Wounding Stress Increases the Phenolic Content and Antioxidant Capacity of Purple-Flesh Potatoess (Solanum tuberosum L.). Journal of Agricultural and Food Chemistry, 51, 5296-5300. http://dx.doi.org/10.1021/jf034213u

[90] Reyes, L.F. and Cisneros-Zevallos, L. (2007) Electron-Beam Ionizing Radiation Stress Effects on Mango Fruit (Mangifera indica 1.) Antioxidant Constituents before and during Postharvest Storage. Journal of Agricultural and Food Chemistry, 55, 6132-6139. http://dx.doi.org/10.1021/jf0635661

[91] Reyes, L.F., Villarreal, J.E. and Cisneros-Zevallos, L. (2007) The Increase in Antioxidant Capacity after Wounding Depends on the Type of Fruit or Vegetable Tissue. Food Chemistry, 101, 1254-1262.

[92] Kang, H. and Saltveit, M.E. (2002) Antioxidant Capacity of Lettuce Leaf Tissue Increases after Wounding. Journal of Agricultural and Food Chemistry, 50, 7536-7541. http://dx.doi.org/10.1021/jf020721c

[93] Koskimäki, J.J., Hokkanen, J., Jaakola, L., Suorsa, M., Tolonen, A., Mattila, S., Pirttilä, A.M, and Hohtola, A. (2009) Flavonoid Biosynthesis and Degradation Play a Role in Early Defense Responses of Bilberry (Vaccinium myrtillus) against Biotic Stress. European Journal of Plant Pathology, 125, 629-640. http://dx.doi.org/10.1007/s10658-009-9511-6

[94] Treutter, D. (2006) Significance of Flavonoids in Plant Resistance: A Review. Environmental Chemistry Letters, 4, 147-157. http://dx.doi.org/10.1007/s10311-006-0068-8

[95] Pedras, M.S.C., Zheng, Q.A., Gadagi, R.S. and Rimmer, S.R. (2008) Phytoalexins and Polar Metabolites from the Oilseeds Canola and Rapeseed: Differential Metabolic Responses to the Biotroph Albugo candida and to Abiotic Stress. Phytochemistry, 69, 894-910. http://dx.doi.org/10.1016/j.phytochem.2007.10.019

[96] Koyama, R., Itoh, H., Kimura, S., Mirioka, A. and Uno, Y. (2012) Augmentation of Antioxidant Constituents by Drought Stress to Roots in Leafy Vegetables. HortTechnology, 22, 121-125.

[97] Sánchez-Rodríguez, E., Moreno, D.A., Ferreres, F., Rubio-Wilhelm, M.M. and Ruiz, J.M. (2011) Differential Responses of Five Cherry Tomato Varieties to Water Stress: Changes on Phenolic Metabolites and Related Enzymes. Phytochemistry, 72, 723-729. http://dx.doi.org/10.1016/j.phytochem.2011.02.011

[98] Oueslati, S., Karray-Bouraoui, N., Attia, H., Rabhi, M., Ksouri, R. and Lachaal, M. (2010) Physiological and Antioxidant Responses of Mentha pulegium (Pennyroyal) to Salt Stress. Acta Physiologiae Plantarum, 32, 289-296. http://dx.doi.org/10.1007/s11738-009-0406-0

[99] Løvdal, T., Olsena, K.M., Slimestadc, R., Verheul, M. and Lillo, C. (2010) Synergetic Effects of Nitrogen Depletion, Temperature, and Light on the Content of Phenolic Compounds and Gene Expression in Leaves of Tomato. Phytochemistry, 71, 605-613. http://dx.doi.org/10.1016/j.phytochem.2009.12.014

[100] Park, S., Jeong, W.Y., Lee, J.H., Kim, J.H., Jeong, S.W., Kim, G.S., Bae, D.W., Lim, J.S., Jine, J.S., Lee, S.J. and Shin, S.C. (2012) Determination of Polyphenol Levels Variation in Capsicum annuum L. cv. Chelsea (Yellow Bell Pepper) Infected by Anthracnose (Colletotrichum gloeosporioides) Using liquid Chromatography-Tandem Mass Spectrometry. Food Chemistry, 130, 981-985. http://dx.doi.org/10.1016/j.foodchem.2011.08.026

[101] Kevers, C., Falkowski, M., Tabart, J., Defraigne, J.O., Dommes, J. and Pincemail, J. (2007) Evolution of Antioxidant Capacity during Storage of Selected Fruits and Vegetables. Journal of Agricultural and Food Chemistry, 55, 85968603. http://dx.doi.org/10.1021/jf071736j

[102] Gennaro, L., Leonardi, C., Esposito, F., Salucci, M., Madani, G., Quaglia, G. and Fogliano, G. (2002) Flavonoid and Carbohydrate Contents in Tropea Red Onions: Effects of Homelike Peeling and Storage. Journal of Agricultural and Food Chemistry, 50, 1904-1910. http://dx.doi.org/10.1021/jf011102r

[103] Rodrigues, A.S., Pérez-Gregorio, M.R., García-Falcón, M.S., Simal-Gándara, J. and Almeida, D.P.F. (2010) Effect of Post-Harvest Practices on Flavonoid Content of Red and White Onion Cultivars. Food Control, 21, 878-884. http://dx.doi.org/10.1016/j.foodcont.2009.12.003

[104] Matthes, M. and Schmitz-Eiberger, M. (2009) Polyphenol Content and Antioxidant Capacity of Apple Fruit: Effect of 
Cultivar and Storage Conditions. Journal of Applied Botany and Food Quality, 82, 152-157.

[105] Rodrigues, A.S., Pérez-Gregorio, M.R., García-Falcón, M.S., Simal-Gándara, J. and Almeida, D.P.F. (2011) Effect of Meteorological Conditions on Antioxidant Flavonoids in Portuguese Cultivars of White and Red Onions. Food Chemistry, 124, 303-308. http://dx.doi.org/10.1016/j.foodchem.2010.06.037

[106] Holopainen, J.K. and Gershenzon, J. (2010) Multiple Stress Factors and the Emission of Plant VOCs. Trends in Plant Science, 15, 176-184. http://dx.doi.org/10.1016/j.tplants.2010.01.006

[107] Scalzo, J., Politi, A., Pellegrini, N., Mezzetti, B. and Battino, M. (2005) Plant Genotype Affects Total Antioxidant Capacity and Phenolic Contents in Fruit. Nutrition, 21, 207-213. http://dx.doi.org/10.1016/j.nut.2004.03.025

[108] Zhang, Y., Seeram, N.P., Lee, R., Feng, L. and Heber, D. (2008) Isolation and Identification of Strawberry Phenolics with Antioxidant and Human Cancer Cell Antiproliferative Properties. Journal of Agricultural and Food Chemistry, 56, 670-675. http://dx.doi.org/10.1021/jf071989c

[109] Seeram, N.P., Adams, L.S., Zhang, Y., Lee, R., Sand, D., Scheuller, H.S. and Heber, D. (2006) Blackberry, Black Raspberry, Blueberry, Cranberry, Red Raspberry, and Strawberry Extracts Inhibit Growth and Stimulate Apoptosis of Human Cancer Cells in Vitro. Journal of Agricultural and Food Chemistry, 54, 9329-9339. http://dx.doi.org/10.1021/jf061750g

[110] Vinson, J.A., Hao, Y., Su, X. and Zubik, L. (1998) Phenolic Antioxidant Quantity and Quality in Foods: Vegetables. Journal of Agricultural and Food Chemistry, 46, 3630-3634. http://dx.doi.org/10.1021/jf980295o

[111] Vinson, J.A., Su, X., Zubik, L. and Bose, P. (2001) Phenol Antioxidant Quantity and Quality in Foods: Fruits. Journal of Agricultural and Food Chemistry, 49, 5315-5321. http://dx.doi.org/10.1021/jf0009293

[112] Chun, O.K., Kim, D.O., Smith, N., Schroder, D., Han, J.T. and Lee, C.Y. (2005) Daily Consumption of Phenolics and Total Antioxidant Capacity from Fruit and Vegetables in the American Diet. Journal of the Science of Food and Agriculture, 85, 1715-1724. http://dx.doi.org/10.1002/jsfa.2176

[113] Brat, P., George, S., Bellamy, A., Du Chaffaut, L., Scalbert, A., Mennen, L., Arnault, N. and Amiot, M.J. (2006) Daily Polyphenol Intake in France from Fruit and Vegetables. The Journal of Nutrition, 136, 2368-2373.

[114] Arabbi, P.R., Genovese, M.I. and Lajolo, F.M. (2004) Flavonoids in Vegetable Food Commonly Consumed in Brazil and Estimated Ingestion by the Brazilian Population. Journal of Agricultural and Food Chemistry, 52, 1124-1131. http://dx.doi.org/10.1021/jf0499525

[115] Pinheiro, A.M., Abreu, C.R.A., Maia, G.A., Sousa, P.H.M., Figueiredo, E.A.T., Rocha, E.M.F.F. and Costa, J.M.C. (2011) Evaluation of Quality Characteristics, Bioactive Compounds and Microbiological Quality of Tropical Ready-toEat Fruit Salad. Alimentos e Nutrição, 22, 435-440.

[116] Segantini, D.M., Leonel, S., Lima, G.P.P., Costa, S.M. and Ramos, A.R.P. (2012) Characterization of Peach Fleshes Produced in São Manuel, State of São Paulo. Ciência Rural, 42, 52-57. http://dx.doi.org/10.1590/S0103-84782012000100009

[117] Vieira, L.M., Sousa, M.S.B., Manicini-Filho, J. and de Lima, J.A. (2011) Total Phenolics and Antioxidant Capacity “in Vitro” of Tropical Fruit Pulps. Revista Brasileira de Fruticultura, 33, 888-897. http://dx.doi.org/10.1590/S0100-29452011005000099

[118] Figueiredo, I.C.R., Jaime, P.C. and Monteiro, C.A. (2008) Factors Associated with Fruit and Vegetable Intake among Adults of the City of São Paulo, Southeastern Brazil. Revista de Saúde Pública, 42, 777-785. http://dx.doi.org/10.1590/S0034-89102008005000049

[119] Ferracane, R., Pellegrini, N., Visconti, A., Graziani, G., Chiavaro, E., Miglio, C. and Fogliano, V. (2008) Effects of Different Cooking Methods on Antioxidant Profile, Antioxidant Capacity, and Physical Characteristics of Artichoke. Journal of Agricultural and Food Chemistry, 56, 8601-8608. http://dx.doi.org/10.1021/jf800408w

[120] Yamaguchi, T., Katsuda, M., Oda, Y., Terao, J., Kanazawa, K., Oshima, S., Iankuma, T., Ishiguro, Y., Takamura, H. and Matoba, T. (2003) Influence of Polyphenol and Ascorbate Oxidases during Cooking Process on the Radical-Scavenging Activity of Vegetables. Food Science and Technology Research, 9, 79-83. http://dx.doi.org/10.3136/fstr.9.79

[121] Rocha-Guzmán, N.E., González-Laredo, R.F., Ibarra-Pérez, F.J., Nava-Berúmen, C.A. and Gallegos-Infante, J.A (2007) Effect of Pressure Cooking on the Antioxidant Activity of Extracts from Three Common Bean (Phaseolus vulgaris L.) Cultivars. Food Chemistry, 100, 31-35. http://dx.doi.org/10.1016/j.foodchem.2005.09.005

[122] Gitanjali, D.P.Y. and Shivaprakash, M. (2004) Effect of Shallow Frying on Total Phenolic Content and Antioxidant Activity in Selected Vegetables. Journal Food Science and Technology, 41, 666-668.

[123] Vallejo, F., Tomás-Barberán, F.A., Benavente-García, A.G. and García-Viguera, C. (2003) Total and Individual Glucosinolate Contents in Inflorescences of Eight Broccoli Cultivars Grown under Various Climatic and Fertilisation Conditions. Journal of the Science of Food and Agriculture, 83, 307-313. http://dx.doi.org/10.1002/jsfa.1320

[124] Barroga, C.F., Laurena, A.C. and Mendoza, E.M.T. (1985) Polyphenols in Mung Bean (Vigna radiata (L.) Wilczek): 
Determination and Removal. Journal of Agricultural and Food Chemistry, 33, 1006-1009.

[125] Miglio, C., Chiavaro, E., Visconti, A., Fogliano, V. and Pellegrini, N. (2008) Effects of Different Cooking Methods on Nutritional and Physicochemical Characteristics of Selected Vegetables. Journal of Agricultural and Food Chemistry, 56, 139-147. http://dx.doi.org/10.1021/jf072304b

[126] Turkmen, N., Sari, F. and Velioglu, Y.S. (2005) The Effect of Cooking Methods on Total Phenolics and Antioxidant Activity of Selected Green Vegetables. Food Chemistry, 93, 713-718. http://dx.doi.org/10.1016/j.foodchem.2004.12.038

[127] Dini, I., Tenore G.C. and Dini, A. (2013) Effect of Industrial and Domestic Processing on Antioxidant Properties of Pumpkin Pulp. LWT—Food Science and Technology, 53, 382-385. http://dx.doi.org/10.1016/j.lwt.2013.01.005

[128] Lima, G.P.P., Lopes, T.V.C., Rossetto, M.R.M. and Vianello, F. (2009) Nutritional Composition, Phenolic Compounds, Nitrate Content in Eatable Vegetables Obtained by Conventional and Certified Organic Grown Culture Subject to Thermal Treatment. International Journal of Food Science \& Technology, 44, 1118-1124. http://dx.doi.org/10.1111/j.1365-2621.2009.01928.x

[129] Cohen, M.F., Sakihama, Y. and Yamasaki, H. (2001) Roles of Plant Flavonoids in Interactions with Microbes: From Protection against Pathogens to Mediation of Mutualism. In: Pandalai, S.G., Ed., Recent Research Developments in Plant Physiology, Vol. 2, Research Signpost, Trivandrum, 157-173.

[130] Link, L.B. and Potter, J.D. (2004) Raw versus Cooked Vegetables and Cancer Risk. Cancer Epidemiology Biomarkers \& Prevention, 13, 1422-1435.

[131] Van Buggenhout, S., Sila, D.N., Duvetter, T., Van Loey, A. and Hendrickx, M. (2009) Pectin in Processed Fruits and Vegetables. Part III-Texture Engineering. Comprehensive Reviews in Food Science and Food Safety, 8, 105-117.

[132] de Ancos, B., González, E.M. and Cano, M.P. (2000) Ellagic Acid, Vitamin C, and Total Phenolic Contents and Radical Scavenging Capacity Affected by Freezing and Frozen Storage in Raspberry Fruit. Journal of Agricultural and Food Chemistry, 48, 4565-4570. http://dx.doi.org/10.1021/jf0001684

[133] Rodrigo, K.A., Rawal, Y., Renner, R.J., Schuwartz, S.J., Tian, O., Larsen, P.E. and Mallery, S.R. (2006) Suppression of the Tumorigenic Phenotype in Human Oral Squamous Cell Carcinoma Cells by an Ethanol Extract Derived from Freeze-Dried Black Raspberries. Nutrition and Cancer, 54, 58-68. http://dx.doi.org/10.1207/s15327914nc5401_7

[134] Gee, J.M. and Johnson, I.T. (2001) Polyphenolic Compounds: Interactions with the Gut and Implications for Human Health. Current Medicinal Chemistry, 8, 1245-1255. http://dx.doi.org/10.2174/0929867013372256

[135] Manach, C., Williamson, G., Morand, C., Scalbert, A. and Rémésy, C. (2005) Bioavailability and Bioefficacy of Polyphenols in Humans. I. A Review of 97 Bioavailability Studies. The Americal Journal of Clinical Nutrition, 81, 230S242S.

[136] Manach, C., Scalbert, A., Morand, C., Rémésy, C. and Jiménez, L. (2004) Polyphenols: Food Sources and Bioavailability1'2. The Americal Journal of Clinical Nutrition, 79, 727-747.

[137] Ito, H., Gonthier, M.P., Manach, C., Morand, C., Rémésy, C. Mennen, L., and Scalbert, A. (2005) Polyphenol Levels in Human Urine after Intake of Six Different Polyphenol-Rich Beverage. British Journal of Nutrition, 94, 500-509. http://dx.doi.org/10.1079/BJN20051522

[138] Mullen, W., Borges, G., Lean, M.E.J., Roberts, S.A. and Crozier, A. (2010) Identification of Metabolites in Human Plasma and Urine after Consumption of a Polyphenol-Rich Juice Drink. Journal of Agricultural and Food Chemistry, 58, 2586-2595. http://dx.doi.org/10.1021/jf904096v

[139] Skibola, C.F. and Smith, M.T. (2000) Potential Health Impacts of Excessive Flavonoid Intake. Free Radical Biology and Medicine, 29, 375-383. http://dx.doi.org/10.1016/S0891-5849(00)00304-X

[140] Halliwell, B. (2003) Plasma Antioxidants (Communication Arising): Health Benefits of Eating Chocolate? Nature, 426, 787. http://dx.doi.org/10.1038/426787a

[141] Halliwell, B. (2007) Dietary Polyphenols: Good, Bad, or Indifferent for Your Health? Cardiovascular Research, 73, 341-347. http://dx.doi.org/10.1016/j.cardiores.2006.10.004 


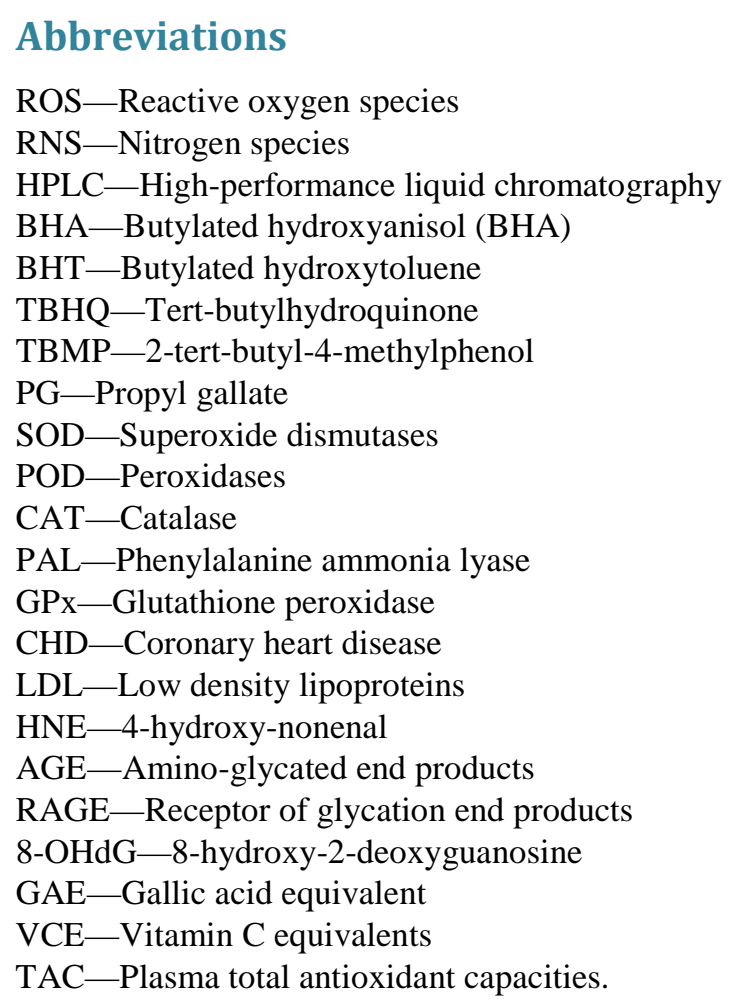

